Nicolas Ruytenbeek*

Ghent University - Faculty of Arts and Philosophy, Department of Translation, Interpreting and Communication, Ghent, Belgium

nicolas.ruytenbeek@ugent.be

*corresponding author

\title{
Do indirect requests communicate politeness? An experimental study of conventionalized indirect requests in French email communication
}

Short title: Do indirect requests communicate politeness?

Size: 74,026 characters with spaces

\begin{abstract}
This article addresses the relationship between linguistic politeness and addressee status in the performance of written requests in French. According to a first view, conventionalized Can you followed by a verbal phrase (in short, Can you VP?) "indirect requests" (IRs) are preferred because they enable speakers to convey politeness effects absent in imperatives. According to an alternative view, Can you VP? is the standard polite request form in written communication because it avoids impoliteness implications. To test these two competing hypotheses, I carried out a production task experiment with 122 native speakers of Belgian French writing email requests. In this experiment, addressee status was manipulated. An important finding is that higher addressee status does not increase the frequency of Can you $V P$ ? requests. Instead of using Can you VP? more often when they address higher status people, the participants used specific politeness markers such as formal greetings and the Vform of address. These results disconfirm the hypothesis that Can you VP? is used to convey
\end{abstract}


extra politeness effects and suggests instead that people use such IRs to avoid the risk of being considered impolite.

Keywords: requests, email, politeness, social status, relevance theory

\section{Introduction}

Language is used to perform social actions such as, for example, informing about a state of affairs, asking a question, wishing someone good luck. These actions, which are accomplished by way of uttering sentences, are called "speech acts" (SAs) (Austin 1962, Searle 1969). This article concerns "directive" speech acts according to a working definition, they consist in telling someone to perform some action.

A reason that makes directive SAs, such as requests, an interesting topic of research is the large variety of forms that are used to perform them. If one wishes to request that someone close the window, one can utter one of the following sentences: the imperative sentence in (1), the declarative sentence in (2), the interrogative sentences in (3) and (4), or even the declarative sentence in (5).

(1) Close the window!

(2) You must close the window.

(3) Can you close the window?

(4) Is it possible to close the window?

(5) It's cold in here.

Even though the list of examples could be made much longer (see, for instance, Searle 1975), the different forms we use as directives cannot be reduced to the sole imperative.

Available research relevant to the production of directives mainly concerns crosscultural differences in the distribution patterns of request forms and politeness markers (for a review with a focus on the varieties of English, see Flöck 2016). A major finding of these 
studies is that indirect requests (IRs) consisting in interrogatives about the addressee's ability to do some action, such as, in particular, Can you VP? illustrated in (3), are preferred over imperative sentences in many situations. In fact, imperatives appear to be rare except in informal spoken conversations, where they are commonly used for the performance of directives (see, e.g., De Clerck 2006; Van Olmen 2011; Flöck 2016).

A substantial number of empirical studies of (im)politeness in SAs are in line with Brown and Levinson's (1987) politeness theory, according to which indirectness consists in a set of linguistic strategies that enable speakers to successfully communicate while avoiding offending their addressees. According to the graded notion of indirectness assumed in the literature, "direct" and "indirect" refer to the extremes of a scale of in/directness, with imperatives being the most "direct" request forms, and hints the most "indirect" forms (Leech 1983; Blum-Kulka and Olshtain 1984; Blum-Kulka 1987; Brown and Levinson 1987; BlumKulka et al. 1989). The strategies used to ground the request SA, to mitigate the force of the request, as well as the closing formulae such as greetings, phatic elements and thanks, have been analyzed in some detail within the framework developed by Blum-Kulka et al. (1989), which will be used in the present article to analyze requests performed in an experimental setting.

Despite considerable attention in the literature, several issues concerning the relationship between request forms and degrees of politeness have been neglected. In particular, it remains unclear whether the use of conventionalized IRs such as (3) and of nonconventionalized IRs such as (4) can be explained by extra politeness effects absent in imperatives.

(1) Close the window! (repeated)

(3) Can you close the window? (repeated)

(4) Is it possible to close the window? (repeated) 
Although empirical studies have addressed the relationship between (im)politeness and in/directness in English, in the case of French, available data bearing on this issue are almost non-existent. In addition, the influence of contextual parameters such as hierarchical status, social distance, and the imposition of the request on the choice of request forms deserves more attention. To address these shortcomings, I will present the results of a production task experiment, in which native speakers of French write email requests to higher-status vs. equal status addressees. I will propose a pragma-linguistic analysis of these data based on BlumKulka and Olshtain (1984) and Blum-Kulka et al.’s (1989) Cross Cultural Speech Act Realization Project (CCSARP) framework. According to a prima facie natural hypothesis, Can you VP? should be more frequent when A is higher in status, because the expected degree of politeness positively correlates with A's social status. Evidence against this hypothesis would be that Can you VP? requests are no more frequent for higher-status addressees, and that other linguistic means are used to increase the politeness of the message.

This paper is structured as follows. In Section 2, I first discuss the hypothesis that the use of Can you VP? as an IR can be explained by the communication of extra politeness effects, which imperative requests would lack. I also consider an alternative hypothesis, according to which Can you VP? does not convey extra politeness, but, rather, enables speakers to avoid being perceived as impolite. Then I offer an overview of the available literature concerning the relationship between politeness and in/directness in French, and concerning politeness and addressee status, and politeness in email communication. The experimental study presented in Section 3 tests the two hypotheses about the use of conventionalized IRs. In this experiment, native speakers of French perform email requests. Playing the role of the editor of a student journal, the participants are instructed to request another person to send them an article; the addressee (A) of the request is either a higher status or an equal status person. The results of this experiment are presented in Section 4, and 
Section 5 contains a discussion of these findings in terms of the hypothesis that conventionalized Can you VP? is used to convey extra politeness. The major implication is that this hypothesis proves untenable. Section 6 presents the conclusion of the article and outlines several suggestions for further research on indirectness and politeness in email communication.

\section{Indirect requests and politeness effects}

The choice of indirect vs. imperative requests relates to Brown and Levinson's (1987) politeness theory. These authors define A's "negative face" in terms of A's freedom to do only what he wants to and his will that others do not impede his actions. On the one hand, directive SAs constitute face-threatening behavior insofar as A's negative face is threatened when $\mathrm{S}$ is telling him what to do. For Brown and Levinson (1987: 130-144), if S wants to avoid such emotional costs for $\mathrm{A}$, while at the same time making her communicative intention clear enough, she resorts to conventionalized indirection. On the other hand, according to these authors, a higher degree of face-threat correlates with higher addressee status; a higher degree of politeness is therefore expected when speakers address individuals who are hierarchically superior to them. For Brown and Levinson, by means of conventionalized IRs, S would communicate to A her intention to be polite, that is her concern for A's face-needs (Fraser 2005). Thus, instead of uttering (1), she could opt for (3) or (6).

(1) Close the window. (repeated)

(3) Can you close the window? (repeated)

(6) You can close the window.

A natural intuition is that, in general, conventionalized IRs achieve a higher degree of politeness than imperatives. This relates to the hypothesis, discussed in the next subsection, that conventionalized Can you VP? IRs are used to increase the politeness of a message. 
However, according to an alternative hypothesis, the use of Can you VP? should not be explained by an increase in politeness, but, rather, by the desire to avoid being perceived as impolite (see Section 2.2).

\subsection{The "extra politeness" hypothesis}

The communication of linguistic politeness is conceived of as a major reason for opting for IRs such as Can you VP? instead of direct requests (Searle 1975: 64; Brown and Levinson 1987: 71-84). It is often suggested for (3) that it is a polite way to phrase a request, the interrogative form of the sentence making it sound more polite than the corresponding imperative (e.g., Searle 1975; Pérez Hernández and Ruiz de Mendoza 2002; Pérez Hernández 2013).

(3) Can you close the window? (repeated)

According to this explanation, unlike the imperative (1), (3) expresses a question, and a question straightforwardly provides the addressee with the possibility to refuse to comply with the request by giving a "no" answer to the question. Because of this, Can you VP? could be used in some situations to increase the politeness of a message in comparison with the imperative alternative - this is what I call the "extra politeness hypothesis". However, this sort of explanation is not completely satisfactory for the reason that addressees can refuse to comply with a request, regardless of the linguistic form used. As a consequence, the intuition that (3) is more polite than the imperative (1) still needs an explanation.

There are several reasons for performing an IR rather than an imperative request. Even though indirect SAs have been approached in terms of strategic choices on the part of speakers (Brown and Levinson 1987; Pinker et al. 2008; Lee and Pinker 2010), empirical evidence suggests that the performance of such SAs is not always strategic (Terkourafi 
2014). ${ }^{1}$ For instance, in the case of young children's directives (My nose is bleeding, I'm cold), indirectness is the only option available to the speaker (S). Unable to identify the action that would help them satisfy their needs, children use negative state remarks to elicit assistance from adults (see, e.g., Bates 1976; Ervin-Tripp 1976).

In other situations, indirectness is used to convey multiple meanings, as in I have to work late tonight, implying that A should not wait for $\mathrm{S}$, that A need not make dinner for $\mathrm{S}$, that S will miss her favorite TV show, etc. (Terkourafi 2014: 55-57). In such cases, S's utterance enables A to draw inferences in a direction ratified by S. Relying on mutual knowledge is thus a convenient way for S to highlight her intimacy with A (see also Terkourafi 2011). This clearly applies to non-conventional IRs, but does it apply to conventional ones? It does not seem to be the case that, in general, conventionalized Can you $V P$ ? are used to convey different meanings at the same time.

Appearances notwithstanding, it is doubtful that the communication of politeness is sufficient to explain why conventionalized IRs are preferred over imperative requests in many contexts. This is because the utterance used as an IR may not always communicate a politeness assumption. As Jary (1998b: 2) points out, very often politeness does not attract attention. Opposing Brown and Levinson (1987: 95), Jary argues that, in many cases, linguistic politeness does not belong to the intended message, so that a politeness assumption does not have the status of a conveyed propositional content (Jary 1998b: 13). Under such a view, it makes little sense to assume that (7)-(8) systematically communicate politeness assumptions.

In the same vein, according to Escandell-Vidal (1998: 52), an IR such as (3) or (6) can give rise to the politeness assumption in (7):

\footnotetext{
${ }^{1}$ For a discussion of Pinker et al.'s strategic speaker approach in comparison to Brown and Levinson's (1987) theory, see Soltys et al. (2014).
} 
(7) S told me to close the window, and she did it politely.

(3) Can you close the window? (repeated)

(6) You can close the window. (repeated)

But, like Jary (1998b), Escandell-Vidal (1998; 2004) considers that politeness assumptions are optional. Although she acknowledges that inferential judgments of (im)politeness can in theory occur for any utterance, she claims that the communication of politeness assumptions is infrequent. For a politeness assumption to be communicated, two conditions are required: politeness must be both intentional and manifest. This implies that, in many contexts, the implicature in (7) will not be derived.

Alongside the decoding and the inferential modules assumed in the relevance theoretic framework, Escandell-Vidal (2004: 358-361) proposes a "social module". This module would yield a set of representations on socially accepted behavior while operating an online analysis of perceived pieces of behavior. As a consequence, higher-level (im)politeness representations can also be derived in the case of imperative requests, which indicates that (im)politeness assumptions are not specific to conventionalized IRs. While empirical evidence for a social module is provided by Brothers and Ring (1992), a more nuanced perspective is proposed by Karmiloff-Smith (1992) and Karmiloff-Smith et al. (1995), who do not endorse a Fodorian notion of modularity. Within the relevance theoretic framework, in Chen's (2014) model of politeness perception, utterance interpretation activates social knowledge about the use of polite expressions and politeness strategies; this information is stored in the interpreter's long-term memory as the content of frames.

Finally, Terkourafi $(2003 ; 2008)$ considers politeness, impoliteness and rudeness as perlocutionary effects of S's utterance. Accordingly, a politeness or impoliteness assumption can - but need not - be achieved as a consequence of S's utterance. Additional arguments against the view that polite utterances result in "politeness implicatures" are discussed in 
Haugh $(2015,149-158)$, who considers that politeness is best defined as an evaluation of the attitude conveyed by an utterance, rather than as a level of meaning communicated by means of an utterance. ${ }^{2}$

\subsection{The "avoidance of impoliteness" hypothesis}

The previous discussion strongly suggests that conventionalized IRs do not always trigger extra cognitive effects about politeness absent in their imperative counterparts. Assuming the absence of such politeness effects, one wonders why conventionalized IRs are preferred to imperatives in the first place. A solution to this issue is to consider that the performance of conventionalized IRs of the Can you VP? type is beneficial to S. In other words, S can choose to perform a request by using the conventionalized Can you VP? rather than an imperative, because the conventionalized expression matches her preferences better than the imperative would (cf. Sperber and Wilson 1995, 266-271). This provides an explanation why Can you $V P$ ? are common in written communication: even though a conventionalized IR does not convey a politeness assumption, it is preferred because it makes it possible for speakers to avoid being perceived as impolite. According to Jary (1998b: 2-3), the choice of "polite" forms such as conventionalized IRs is, above all, explained by S's desire to preserve her status within a social community. In a similar vein, Davis (1998: 119) points out that central matters for S regard, first, the amount of effort she produces in conveying her assumptions and, second, the possible consequences of the utterance's form for her reputation (see also Pinker et al. 2008; Lee and Pinker 2010).

Discussing the difference between imperative and indirect directives from a relevance theoretic perspective, Jary (1998a: 160) argues that in communicating her desire by means of

\footnotetext{
${ }^{2}$ For an experimental study of the politeness evaluations associated with the forms used as IRs, see Clark and Schunk (1980).
} 
an imperative request, $\mathrm{S}$ makes manifest her belief that this desire be relevant for A. The recognition of this premise is required for A to access the intended request interpretation. For Jary, the choice of conventionalized expressions for the performance of requests is motivated by S's further desire to avoid conveying hazardous implications such as the assumption that, because her desire is relevant for A, S is "superior" to A. Thus, according to Jary, the reason that indirect directives are preferred to imperative directives in some situations is that they match S's preferences better than imperatives do.

There is, however, a problem with this argument: A's compliance with an IR such as (3) implies that S's desire is relevant for A, just as it is when the imperative (1) is used as a request.

(1) Close the window. (repeated)

(3) Can you close the window? (repeated)

In such cases, understanding that a request has been made implies that S's desire has been perceived by A as a reason to comply. Even though, in relevance theory, only imperative requests encode desirability, the speaker's desire that A do some action will be relevant for A whether the uttered sentence is imperative, interrogative or declarative. Thus, contrary to what Jary suggests, both an imperative request and a conventionalized IR may convey the implicature that "S is superior to A". As a consequence, one fails to see why conventionalized IRs such as Can you VP? match S's preferences better than imperatives do. The explanation I propose is based on the incompleteness of the interrogative sentence-type and on the meaning of the modal can present in this expression.

First, unlike sentences belonging to the declarative sentence-type, such as You can $V P$, interrogatives such as Can you VP? encode some degree of incompleteness. For instance, Fiengo (2007) builds on the observation that interrogative sentences are tools that are incomplete in one respect or another, and he argues that displaying such incompleteness is a 
convenient way for speakers to get missing information from addressees, as in the SAs of questioning and of requesting (see also Levinson 2012).

Second, by virtue of their lexical semantics, expressions such as Can you VP?/You can VP encode a force dynamic pattern of "enablement" (Johnson 1987: 52-53; Sweetser 1990: 52-53; Talmy 2000: 444-447). Accordingly, Can you VP?/You can VP expressions refer to the addressee's internal capacity or "power" to act. Unlike imperatives and You must $V P$ declaratives, the force dynamic pattern of ability interrogatives cannot be directly specified with force exertion at the pragmatic level (Ruytenbeek 2017: chap. 3). This hypothesis may explain not only why IR expressions are often responded to with a yes answer, but also why these sentences are unmarked polite forms (cf. Terkourafi 2015).

Unlike Can you VP?, Is it possible to VP? is not a conventionalized IR expression insofar as it has not been gradually associated with an indirect directive meaning over time (or at least much less so than Can you VP?). A corpus-based study of IRs in the literary database Frantext supports the view that, in French, (8) is most often used with its direct "question" meaning, in contrast to (9) that has a preferred "request for action" meaning (Ruytenbeek et al. 2017).

(8) Est-il possible de VP?

'Is it possible to VP?'

(9) Pouvez-vous VP?

'Can/may you VP?'

The total number of utterances of (9) in the studied subset of the Frantext corpus (i.e., 365) was about 6 times larger than the total number of utterances of (8) (i.e., 63). For (9), IR uses were the most frequent (71\%), followed by direct questions $(25 \%)$, and rhetorical questions (4\%). By contrast, for (8), direct questions were the most frequent (70\%), followed by IRs $(16 \%)$ and rhetorical questions (14\%). A plausible reason why (8) has not conventionalized 
as an IR is that this expression presents a potential action as being more external to A, whereas in the case of (9), which includes a second-person pronoun, A is identified with the agent of the action. Even though these data should not be taken as evidence that, in French, Can you VP? is preferred over imperatives in any context, it indicates that this construction is strongly associated with a request interpretation (politeness in French requests is discussed in Section 2.3.1 below).

Thus, even though Can you VP? does not always give rise to extra cognitive effects or perlocutionary effects about politeness absent in imperatives, this expression is often preferred to the imperative because it is considered (more) polite qua expression. The fact that Can you VP? corresponds to a "baseline" for politeness evaluations explains why it is commonly used as an IR: it enables speakers to avoid impoliteness. If this hypothesis is correct, one expects Can you VP? to be a frequent request form in many contexts. As for the non-conventionalized Is it possible to VP?, this form makes more likely that a "request for information" meaning is intended, and asking such a question (as a means to perform the IR) would increase the politeness of the message. Accordingly, Is it possible to VP? is expected to be more frequent when face-threat is likely to be an issue, as when addressing a higherstatus person.

As I have shown, there are two major hypotheses concerning the use of Can you VP? in written communication. On the one hand, Can you VP? is used to communicate extra politeness effects absent in imperative directives. On the other hand, Can you VP? enables speakers to avoid being perceived as impolite, while making their directive intent clear enough. To test these two competing hypotheses, I present the data from a production task experiment involving French email requests, in which I investigate the influence of social status asymmetries between $\mathrm{S}$ and $\mathrm{A}$ on the form and structure of the requests. Such an approach is all the more welcome because the issue of whether conventionalized IRs are used 
to increase politeness remains unexplored. Before addressing in more detail this experimental study, I will first review available empirical literature devoted to politeness and indirectness in French. I will also address empirical studies concerning the influence of the social variable of addressee status on the production of written requests (Section 2.3.2), and the politeness of email requests in an academic setting (Section 2.3.3). Then, I will show how my approach, while complementing the findings of these studies, departs from them because of its methodology.

\subsection{Overview of related work}

\subsubsection{French politeness}

Available literature concerning the production of requests by native speakers of French is scarce. French request forms have been studied by several authors (e.g., Roulet 1980; Kerbrat-Orecchioni 1994; Manno 2002), but unfortunately these contributions are not corpusbased and do not focus on authentic data.

To the best of my knowledge, no experimental studies concerning the production of email requests in French have been conducted. However, the production of French requests in conversational contexts and daily interactions is well documented. For instance, KerbratOrecchioni (2004) analyzed the politeness of requests in a bakery. She found that imperatives were very rare, and always modified with s'il vous plait ('please'). ${ }^{3}$ The vast majority of forms were IRs consisting of want statements such as (10), declaratives such as (11), and availability interrogatives such as (12).

(10) J'aimerais NP.

'I would like NP.'

(11) Je prendrai/vais prendre NP.

\footnotetext{
${ }^{3}$ A comparative discussion of the frequency of $s$ ' $i l$ vous plait and other politeness markers in French vs. Dutch is offered in Van Mulken (1996). Danblon et al. (2004) provide empirical evidence concerning the use, in Belgian French, of s'il vous plait as a presentative form similar to voici/voilà ('here it is'), as when a speaker is handing over an item to her addressee.
} 
'I'll take NP.'

(12) Vous avez NP?

'Do you have NP?'

Another interesting study is Warga's (2005), in which request forms were compared between native and non-native speakers of French - I only report the results for the native speakers. Combining the discourse completion task (DCT) method with a spoken version of the DCT questionnaire, Warga manipulated the parameter of addressee status (either a fellow student or a teacher), while the social distance and the costs associated with the requested action remained similar across the situations. First, conditionals were more frequent than present tense forms. Second, IRs such as Can/could you VP? were the most frequent request forms $(77 \%)$, ahead of, for instance, want statements (10\%) and hedged performatives (9\%).

Unfortunately, Warga does not tell us whether the distribution of request forms varied according to addressee status in the data for the native speakers. In addition, the results of both Kerbrat-Orecchioni’s (2004) and Warga's (2005) studies do not provide evidence directly relevant to the issue of whether Can you VP? is used to increase the politeness of a message, in particular when it is addressed to a higher-status person. However, it is plausible to assume, on the basis of these two studies, that Can you VP? is ubiquitous in French conversations and in written communication. Similar findings have been made for American English and British English. For instance, ability interrogatives are the most frequent request strategy when the data collection method is the DCT (Flöck 2016: 174-186). However, in informal conversations, imperatives come first (Flöck 2016: 118-128) and IRs are less frequent (see also Aijmer 1996). ${ }^{4}$

\footnotetext{
${ }^{4}$ On the differences in terms of the variety of forms collected in written and spoken DCTs, see Yuan (2001).
} 


\subsubsection{Politeness and addressee status}

According to Brown and Levinson (1987), speakers performing face-threatening SAs such as directives take into account the sociological variables of power (the perceived power relationship between $\mathrm{S}$ and $\mathrm{A}$ ), the social distance between $\mathrm{S}$ and $\mathrm{A}$ (a high social distance corresponds to a low degree of familiarity), and the ranking of impositions of the SA in the culture (for a directive SA, impositions are the costs that are associated with the performance of the requested action for A) (Brown and Levinson 1987: 68-83). On the basis of this information, speakers select a strategy for the performance of the directive, which involves paying some attention to the form of the SA. One example of power asymmetry between $\mathrm{S}$ and $\mathrm{A}$ is when $\mathrm{A}$ is higher in status relative to $\mathrm{S}$, which raises the issue of whether increased politeness for higher-status addressees translates into the choice of conventionalized IRs over imperatives.

Brown and Levinson's view that degree of politeness positively correlates with addressee relative status has received cross-cultural support. For instance, Holtgraves and Yang (1990, Experiment 3) provide evidence that the form of a request influences the perception of S's relative status. In their experiment, S was perceived as lowest in status when the request was a hint, and highest in status when the request was performed with an imperative. ${ }^{5}$ This suggests that the use of indirect request forms is preferred by lower-status English speakers, in particular when they address higher-status interlocutors (see also Leichty and Applegate 1991; Lim and Bowers 1991). Concerning the relationship between A's status and the forms of emails, it has been shown that changes in the structure of an email reflect the knowledge that $\mathrm{A}$ is high in status, in particular in the variety of Spanish expressions used in the opening and in the closing of messages (Bou-Franch 2011). Finally, in a discourse

\footnotetext{
5 The participants in Holtgraves and Yang's (1990) study were American and Korean students.
} 
completion task (DCT), Saeli (2016) provides evidence for a significant effect of A's relative status on the form and structure of Persian requests. In his study, requests were addressed by graduate students to professors (higher-status), peers (equal-status), and undergraduate students (lower-status). The requests to higher-status people were more formal and longer than those addressed to lower-status and equal-status people. However, the authors of these different studies do not report on differences in the frequency of use of Can you VP? requests according to addressee status.

\subsubsection{Politeness in email communication}

A relevant body of research concerns the indirectness/politeness of electronic requests addressed to faculty members. In English, this topic has been dealt with by several empirical studies, with a focus on the influence of request imposition on the politeness of the utterance. "Degree of imposition" refers to Brown and Levinson's (1987: 77) notion of a "ranking of impositions" (see Section 2.3.2). For instance, Biesenbach-Lucas (2007) investigated, on the basis of spontaneous emails sent by students to professors, whether request strategies vary with the degree of imposition of the requests. Biesenbach-Lucas' corpus consisted of emails in which the power and social distance between the interlocutors were stable, but in which the degree of imposition associated with the request varied. Three sorts of requests constituted the corpus: requests for an appointment (low imposition), requests for feedback on a written work (moderate imposition), and requests for an extension of a due date (high imposition). The level of imposition of the request also varied according to the urgency of the requested favor. Following Blum-Kulka and Olshtain's (1984) cross-cultural speech act realization project (CCSARP) coding scheme, Biesenbach-Lucas analyzed the proportion of request forms in terms of "degrees of (in)directness": hints such as (13) are more indirect than questions about the preparatory conditions such as (14), which are in turn more indirect than strategies including want statements such as (15), elliptic constructions such as (16) (but also 
imperatives, performatives, need statements, etc.). The examples given illustrate a request for feedback on a written work.

(13) I'm having a very difficult time in figuring out how to put these lesson materials together.

(14) Would you mind taking a look and giving me some suggestions?

(15) I would like your suggestions.

(16) Any comments?

First, requests for feedback involved a large majority of "direct" strategies, and hints were more frequent than interrogatives about the preparatory conditions. Second, requests for appointment involved as many "direct" strategies as interrogatives about the preparatory conditions, but no hints. Third, more than a half of the requests for extension of due date were of the "preparatory condition" type, and more than $30 \%$ were hints. These results suggest that the degree of imposition has an influence on the strategies used in the performance of the requests: the stronger the imposition, the more frequent the preparatory interrogative request forms. However, it is unclear in Biesenbach-Lucas' data whether Can you VP? interrogatives were more frequent in the high imposition condition than in the other imposition conditions, and whether Can you VP? was more frequent than other preparatory interrogatives in these different conditions.

In a similar vein, Chejnová (2014) collected 260 email messages sent by university students in the Czech Republic. These messages contained a high imposition request for action and were addressed to a lecturer. The most frequent request forms were hedged performatives such as (17), followed by interrogatives about the possibility to do the action such as (18), interrogatives about permission such as (19), performatives such as (20), and interrogatives about A's ability/willingness to do the requested action, such as (21).

\section{(17) Chtěla bych vás poprosit o zapsání do kurzu.}

'I would like to ask you to enrol me in the course.' 
Bylo by možné zapsat mě do kurzu?

'Would it be possible to enrol me in the course?'

(19) Mohla bych vás požádat o zapsání do kurzu?

'Could I ask you to enrol me in the course?'

(20) Žádám vás o zapsání do kurzu.

'I am asking you to enrol me in the course.'

(21) Mohla byste mé zapsat do kurzu?

'Could you enrol me in the course?'

In addition to the variety of request forms used, Chejnová observed that the students often resorted to internal modifications, such as conditional and lexical downgraders, to mitigate the directive force of their messages. For instance, $25 \%$ of the requests included consultative devices such as Don't you think, and $17 \%$ included the marker please, which was probably used more for considerations of politeness than to make salient the illocutionary force of the request. By contrast, lexical upgraders such as the intensifiers really in I ask you really..., and once more in I ask you once more..., which can be used to stress the imposition on A, were less frequent ( $6 \%$ in total). As for the external modifications of the request, thanking A in advance was part of $86 \%$ of the messages. A considerable number of requests (43\%) were grounded, that is, preceded or followed by a justification for the request. In contrast to the frequency of downgraders, aggravating moves, such as emphasis on urgency/positive outcome, complaints, and criticisms were rare in the data (9\%). The results of Chejnová's (2014) study also suggest, on the one hand, that the frequency of lexical downgraders positively correlates with the degree of imposition and, on the other hand, that the frequency of aggravating moves and of lexical upgraders negatively correlates with the degree of imposition. However, one cannot draw any conclusion as to whether the use of the conventionalized Mohla byste VP ('Could you VP?') or the less conventionalized Bylo by možné VP ('Would it be possible to VP?') is more frequent with higher status addressees than with equal and lower-status addressees. 
Summing up, even though the studies reviewed above reflect a strong interest in the relationship between the form of email requests and degrees of politeness, several issues remain unaddressed. The first issue is whether the use of Can you VP? in emails can be explained by extra politeness effects, as in the case of messages addressed to higher-status people. A second more general question concerns the variety or politeness markers used to address higher status vs. equal and lower-status individuals.

Furthermore, there are two major problems with the empirical studies of request production carried out thus far. First, DCT approaches have been criticized on the grounds that the data collected with this method are not representative of the participants' actual behaviors (see Flöck 2016: 43-59 for a discussion; see also Yuan 2001). This criticism is supported by important differences in the relative frequencies of imperative vs. indirect request forms produced, whether the data are elicited or not. Second, a related problem, which concerns the corpus-based approaches to request production, is that they did not control for some possible sources of variability in the data. Such uncontrolled parameters include, to only name a few, demographic and sociolinguistic differences between speakers and addressees, and differences in the content of the request, or in the course of action in which the performance of the request takes place.

The methods of investigation of request production in the studies discussed above are thus far from perfect and they are limited, consisting either of analyses of corpora (including variables that are hard to control for) or in DCT questionnaires, which are unlikely to result in authentic discourse. Unlike these approaches, I use a role play methodology that consists of explicitly instructing participants to perform an email request in an academic context. This method, which is closer to natural language use than the DCT, still remains artificial to some extent (Leech 2014: 253-254), as the experiment is presented as a situation test, and background information is provided to the participants. However, three advantages of such an 
approach are that 1) the data is highly controlled insofar as the content of the request is identical for all the participants, 2) the relative social status of the addressee is explicitly stated in the instructions, 3) the participants have a lot of flexibility in how to write their message.

\section{Methodology}

\subsection{Hypotheses}

In the experimental approach reported below, I use a production task in which student participants request that their addressee send them a missing document. Scenarios in which a student requests the notes of a fellow student have frequently been used in previous research on the production of requests (for an overview, see Ogiermann 2009). In such scenarios, the relationship between the interlocutors is defined in terms of low social distance and equal hierarchical status, which suggests that potential threat to A's negative face is not an issue. By contrast, requesting something from a higher-status person, such as a professor, is more likely to involve strategies to save A's negative face (cf. Section 2). In the present study, to investigate whether the conventionalized IR Can you VP? is used to increase politeness, the power relationship between $\mathrm{S}$ and A will be manipulated (A will be either equal in status or superior in status to $S)$.

I tested three hypotheses about the form of the requests that the participants were expected to produce.

First, assuming that the conventionalized Can you VP? is used to convey extra politeness effects, one should predict Can you VP? IRs to be more frequent when A is higher in status than when A is equal in status. The reason is that speakers increase the politeness of their messages when they address higher-status people in order to save A's negative face. By contrast, they need not necessarily do so when addressing equal-status people, for whom potential face-threats are less likely to be an issue. 
Second, according to an alternative hypothesis, Can you VP? is not used to convey extra politeness, but, rather, it enables speakers to avoid impoliteness effects. In other words, Can you VP? helps speakers constituting their own face by presenting themselves as "not impolite". As a consequence, Can you VP? should not be more frequent for higher-status than for equal-status addressees.

Third, non-conventionalized Is it possible to VP? can be expected to be more frequent when $\mathrm{A}$ is higher in status than when $\mathrm{A}$ is equal in status for the following reason. Because the IR interpretation is not deeply entrenched in this expression, such non-conventionalized IRs make it more likely that a "request for information" meaning is intended, alongside an additional indirect "request for action" meaning. According to this hypothesis, then, when A is higher in status, it makes sense to perform an IR while at the same time enquiring, with a question, about the plausible obstacle to A's performance of the requested action. Accordingly, non-conventionalized Is it possible to VP? should be more frequent when A is higher in status than when $\mathrm{A}$ is equal in status.

\subsection{Design}

\subsubsection{Participants}

I recruited 122 native speakers of French (mean age 21.5, standard deviation 2.7, range 1729, 90 female); the participants were students at the Universite libre de Bruxelles. None of them had graduated in linguistics or had previous experience with this experimental design. The participants were paid 8 euros for participating in this and two other short experiments, not reported here.

\subsubsection{Procedure and instructions}

The participants were installed in front of an Asus laptop computer in the experimenter's office, and logged on to the mailbox of an email account designed for the purposes of the 
experiment. They received their instructions on a sheet of paper, with the following background:

(22) For this experiment, imagine that you are finalizing the publication of the student journal of the Faculty of Languages, Translation, and Communication at the ULB.

To carry out this task, you will write, one after the other, the following two emails (you have a maximum of 20 minutes).

They were asked to perform the following task: sending an email to another person to ask that person for a contribution in the student journal (the data for the other email are not reported here). It was assumed, on the basis of the instructions provided to the participants, that the content of their emails would contain a request - regardless of the structure or length of the email. When the participants had finished reading their instructions, the experimenter verified that they understood they should act as the person in charge of the finalization of the student journal.

In order to test for the influence of the power variable on request strategies and request forms, the status of the addressee was manipulated. For half of the participants, the addressee of the email was the Dean of the Faculty, for the other half the addressee was a female student. No information about the social distance variable was provided to the participants. Considering that the experiment consisted of a role play, and both the Dean of the Faculty and the fictitious student were not known to the participants, the addressee of their message should be unfamiliar to them, which should result in some degree of formality. The variable of "degree of imposition" was controlled for, insofar as all the participants were asked to perform one and the same request, and the content of the request did not vary according to addressee status.

The instructions were the following:

(23) Le Doyen de la Faculté/Une étudiante, Amandine Castani a oublié de vous envoyer le texte qu'il/elle a rédigé pour la revue. À partir de la messagerie affichée 
sur l'écran de l'ordinateur, écrivez-lui un email en lui demandant de vous envoyer ce texte (adresse du Doyen/d'Amandine Castani : [...]).

- L'objet de l'email est : "revue des étudiants».

- Signez l'email avec vos nom et prénom.

- Quand vous avez terminé d'écrire votre email, appuyez sur " envoyer».

'The Faculty Dean/A student, Amandine Castani forgot to send you the text he/she wrote for the journal. From the email account displayed on the screen of the computer, write an email to him/her, requesting him/her to send you this text (Dean/Amandine Castani's address: [...]).

- Email object is: "student journal".

- $\quad$ Sign the email with your own name and surname. ${ }^{6}$

- When you are done writing your email, click on "send".'

To ensure that all the participants would understand that they had to perform a request, this was made very explicit in the instructions (écrivez-lui un email en lui demandant de vous envoyer ce texte). The request SA expected from the participants thus was that "S requests A to send her/his text to S". Nothing in the instructions prevented the participants from including additional information in their email, as long as they complied with the task.

A maximum of 20 minutes was allowed for the two emails. 6 participants were excluded from the analysis because they had not correctly followed the instructions.

\subsubsection{Data collection and data analysis}

The collected data thus contain one email for each participant. The analysis of the structure and content of the emails was conducted in line with Blum-Kulka and Olshtain's (1984) CCSARP coding scheme (Appendix 1), with the exception that, here, request forms were not classified according to "levels of (in)directness". In accordance with the CCSARP coding scheme, I systematically distinguished the "request head act", that is the utterance by means

\footnotetext{
${ }^{6}$ To check that the participants read all the instructions, the sender's signature was manipulated. Half of the participants were asked to sign the email in their own name, the other half to sign it on behalf of the experimenter. For the participants who did not sign their email or made a mistake in the signature, the data were removed from the analysis.
} 
of which the request is communicated, from peripheral request components. These include the utterances by means of which the participants ground their request, check whether the preconditions for their request SA obtain, etc. (see Appendix 1 for French examples with English translations). ${ }^{7}$

The utterances conveying the request head act were classified in terms of the “conventions of means" involved (cf. Searle 1975; Clark 1979). According to Clark (1979: 432-433), IRs involve conventions of means, and these conventions are "about which sentences can be used for which indirect speech acts". They concern the general cognitive strategies used in the performance of SAs. For instance, Can you VP? involves the convention of means consisting in referring to A's ability to act. The request head acts were classified into the following conventions of means (Appendix 2): imperatives, obligation statements, preparatory interrogatives, expression of S's desire/need, explicit performatives, hedged performatives, hints such as negative state remarks (e.g., I have not received NP), and formulaic (e.g., Merci de VP, literally 'Thanks for VPing', which is best translated as 'Please $\left.\mathrm{VP}^{\prime}\right){ }^{8}$

First, frequency counts for the conventions of means were computed. A statistical analysis, consisting in Chi-squared tests for given probabilities, was used to compare the proportion of Can you VP? requests in the higher status and equal status conditions. Then, a post-hoc comparison of external and internal modifications in the two status conditions was carried out using the same procedure.

\footnotetext{
7 The rough collected data as well as the coded data are available on the Open Science Framework (https://osf.io/s26w8/?view_only=b3b152592d244242800d0786631e25bf).

${ }^{8}$ For a discussion of prospective thanking in French directive SAs, see Manno (1999).
} 


\section{Results}

In this production task experiment, I tested the hypothesis that conventionalized Can you $V P$ ?, are used to convey extra politeness effects absent in their imperative counterparts. If the "extra politeness effects" hypothesis is right, Can you VP? should be more frequent when A is higher in status than when $\mathrm{A}$ is equal in status.

$66 \%$ of the requests were formulated with an interrogative about A's ability to perform the action, such as (24). ${ }^{9}$

(24) Pourriez-vous m'envoyer le texte que vous avez rédigé pour la revue?

'Could you send me the text you wrote for the journal?'

The "extra politeness hypothesis" was not borne out: conventionalized Can you VP? was no more frequent in the higher-status condition (27 out of 57) than in the equal-status condition (37 out of 59). Non-conventional Is it possible to VP? and Would it be possible to VP? tended to be more frequent when A was higher in status ( 8 out of 57) than when he was equal in status (4 out of 59). A Chi-squared test for given probabilities indicated that these differences were not statistically significant $\left(\chi^{2}(1, N=116)=2.29, p=.13\right)$.

The data analysis reveals that the participants increased the politeness of their messages addressed to a higher status person. A first indication is that formal greetings were more frequent in the higher status (50 out of 57 messages) than in the equal status condition (36 out of 59 messages) (see Table 1 below). ${ }^{10}$ This difference proved significant $\left(\chi^{2}(1, N=\right.$ 116) $=9.43, p<.01)$. Second, the distribution of V-and T-forms of address differed significantly according to addressee status $\left(\chi^{2}(1, N=116)=21.03, p<.0001\right) .{ }^{11}$ The participants preferred using the V-pronoun vous over the T-pronoun $t u$, even when A was

\footnotetext{
${ }^{9}$ Additional examples with English translations are provided in Appendix 3.

${ }^{10}$ Examples in French with English translations are provided in Appendix 1.

${ }^{11}$ On the distinction between T- and V-forms, see Brown and Gilman (1960). For a discussion of tu, vous, and other forms of address in French, see Martiny (1996).
} 
equal in status, but vous was the only pronoun used with higher status addressees (it was used in only 39 out of the 59 messages in the equal status condition).

Table 1: Frequency of politeness markers for requests to equal vs. higher status addressees

\begin{tabular}{|l|l|l|l|}
\hline & Examples & $\begin{array}{l}\text { Equal } \\
\text { status }\end{array}$ & $\begin{array}{l}\text { Higher } \\
\text { status }\end{array}$ \\
\hline Conventionalized IRs & Can/could you VP? & $37 / 59$ & $27 / 57$ \\
\hline Non-conventionalized IRs & $\begin{array}{l}\text { Is it possible to VP? } \\
\text { Would it be possible to VP? }\end{array}$ & $4 / 59$ & $8 / 57$ \\
\hline Formal greetings & With best wishes, sincerely yours & $36 / 59$ & $50 / 57$ \\
\hline Vous $($ vs. $t$ (u) & & $39 / 59$ & $57 / 57$ \\
\hline
\end{tabular}

These results indicate that French speakers use specific linguistic devices, rather than the conventionalized Can you VP?, to increase the politeness of their message when they address a high status person such as a Faculty Dean. The data collected in this experiment thus disconfirm the hypothesis that, in French, Can you VP? is used to communicate extra politeness effects absent in imperative directives. Extra politeness set aside, the high frequency of Can you VP? in email requests is best explained, then, in terms of the speakers' desire to avoid the impolite implications associated with imperatives.

Let us summarize the results of this experiment. First, the differences in the use of politeness strategies in the equal status and higher status conditions indicate that the participants did not use Can you VP? to be more polite. Rather, they increased the politeness of their requests for higher status addressees by systematically using the V-form of address, and by including formal greetings in the closing of their message. Second, nonconventionalized IRs tended to be more frequent when A was higher in status, but this difference was not significant. Third, the data provide conclusive evidence that ability interrogatives are preferred in email requests in an academic context. Two-thirds of the requests belonged to this convention of means. In comparison, request forms involving other conventions of means, such as imperatives, were rare. 


\section{Discussion}

The results of this production task experiment have several implications for theoretical and empirical approaches to the connections between semantics, pragmatics and social communication.

First, assuming that the degree to which a given expression is conventionalized for the performance of some SA can be measured in terms of relative frequency of occurrence, the collected data indicates that Can you VP? has a high degree of conventionalization qua IR because it largely outnumbers other request forms. This relates to Terkourafi's (2015) notion of conventionality, i.e., the result of a diachronic process of conventionalization, which she defines in terms of a relationship between an expression, a speaker, and a context.

Accordingly, Can you VP? is the standard way for speakers of French to perform email requests in a formal context. The use of Can you VP? cannot be explained by S's desire to communicate extra politeness to her addressee, but, rather, it is best thought of in terms of S's display of her communicative competence. In so doing, she establishes her own face and, by implication, also constitutes her addressee's inasmuch as the expression she uses gives rise to a positive politeness evaluation. The data collected in this study concern the French language, in which requests performed by means of imperatives are largely dispreferred in formal communication (but less so in more informal settings). The conclusions drawn on the basis of these data therefore do not directly generalize to cultures where the use of imperatives is less strongly associated with imposition and face-threat. ${ }^{12}$

Second, the observation that ability interrogatives and, in particular, Can you VP? sentences are preferred for the performance of requests is well in line with the finding that

\footnotetext{
${ }^{12}$ For instance, in Korean, the grammatical system of honorifics plays a more important role in perceived (im)politeness than sentence-types: a deferential imperative is considered more polite than a non-deferential Can you VP? interrogative (see, e.g., Byon 2006; Yu 2011).
} 
these expressions do not entail extra processing costs relative to their imperative and “obligation statement" counterparts (Ruytenbeek et al. 2017): in a context where both the question interpretation and the IR interpretation of Pouvez-vous VP? ('Can you VP?') and Est-il possible de VP? ('Is it possible to VP?') were available, the latter IR interpretations of these stimuli were processed as fast as in the corresponding imperatives. As Terkourafi (2015: 15) puts it, "[such expressions] can be adapted to a wide range of frequently experienced situations with minimal effort and, while they are the most expedient means of achieving politeness, departing from [a] conventionalized expression is also possible and may be associated with either increasing politeness or increasing impoliteness."

Third, these findings can straightforwardly be explained in terms of Sperber and Wilson's (1995) account of utterance interpretation in terms of maximal and optimal relevance. According to the standard relevance theoretic (RT) analysis of verbal communication, the inferential processes involved in utterance interpretation seek to maximize the balance between processing efforts and cognitive effects. Maximal relevance is achieved, for any given degree of effort, when the effects resulting from that effort are greatest, or, for any given level of effect, when the effort required for deriving those effects is minimized (Sperber and Wilson 1995; Sperber and Wilson 1997). Thus, from a RT perspective, Pouvez-vous VP? ('Can you VP?') is maximally relevant because it enables speakers of French to achieve their communicative intention, i.e., to perform a request, while imposing, relative to the imperative, no extra costs to their addressees (as the results of Ruytenbeek et al.'s 2017 experiment indicate). In line with the presumption of optimal relevance, (a) A assumes that S's utterance yields enough cognitive effects for it to be worth processing and (b) A expects $\mathrm{S}$ to choose an utterance that matches as much as possible her preferences and her abilities (Sperber and Wilson 1995: 266-271). Thus considerations of costs and effects are not sufficient to determine whether $\mathrm{S}$ should use an imperative request 
or, rather, an IR. This is because, according to the presumption of optimal relevance, if an interrogative sentence such as Can you VP? is more in agreement with S's preferences and abilities than an imperative, then, if $\mathrm{S}$ is a rational and benevolent speaker, she should perform her request by using Can you VP? and not the imperative. This brings us back to the conventionalization of ability interrogatives, which enables speakers to receive a positive "politeness" evaluation instead of being perceived as rude or impolite.

Fourth, the absence of a significant difference between the number of nonconventionalized IRs (Est-il possible de VP?, i.e., 'Is it possible to VP?') in the high vs. equal status conditions may be due to the fact that, in both conditions, a low degree of familiarity (i.e., a high social distance) between $\mathrm{S}$ and $\mathrm{A}$ was assumed by the participants - even though no information about social distance was included in the instructions of the experiment (see Section 3.2). Accordingly, most participants may have considered the addressee of their message as being unfamiliar to them, which would explain the frequent use of $\mathrm{V}$ - forms of address across the conditions.

\section{Conclusion}

In this article, I investigated the role of Pouvez-vous VP? (in short, Can you VP?) in French polite email requests. I first discussed the seemingly attractive "extra politeness view" according to which the use of Can you VP? as IR can be explained by the communication of politeness effects absent in imperative requests. An alternative hypothesis was also considered: according to this explanation, Can you VP? is used not because it triggers politeness effects but, rather, because it enables speakers to avoid impolite implications.

In a production task involving Belgian native speakers of French, I put to the test the predictions of these two competing hypotheses. On the one hand, according to the "extra politeness view", Can you VP? should be more frequent in the higher-status condition. On the 
other hand, according to the alternative hypothesis, the frequency of Can you VP? should not be influenced by addressee status, and increased politeness for higher-status addressees should be achieved by other linguistic means.

The results of the production task revealed that, contrary to the "extra politeness" hypothesis, people do not adapt their communicative style by using conventionalized Can you VP? more often with higher-status addressees. Rather, they signal deference to the addressee's superior status with formal greetings and the systematic use of the V-pronoun vous. In other words, A's high status does not result in a more frequent use of Can you VP?. These results thus seem to go against Brown and Levinson's (1987) view that a higher power asymmetry between $\mathrm{S}$ and $\mathrm{A}$ increases the potential face-threat of a message, which, in turn, motivates the choice of a more polite utterance. In addition, these findings strongly suggest that the politeness associated with the expression Can you VP? is not addressee-oriented, but the result of S's conforming to the "rules" of formal written communication.

Interestingly, the collected data provide partial support for Brown and Levinson's (1987) view that A's higher status correlates with a high degree of politeness. Insofar as the participants' messages do not only consist of a request head act, but also comprise grounding elements and internal/external modification of the request, increased politeness was achieved in email components outside the request head act. These preferences point to the importance of the level of politeness located at the end of the message, i.e., in the greetings and closing formulae.

In this study, no information about the assumed social distance between $\mathrm{S}$ and $\mathrm{A}$ was given to the participants. However, manipulation of this variable is a promising idea for further research on politeness in French emails. In contrast to the present study, in which participants tended to consider their addressee as being unfamiliar to them, decreased social distance between $\mathrm{S}$ and A could impact request strategies and politeness markers, and the 
differences between the higher-status and the equal-status conditions be reinforced in comparison with the present study. This issue will be dealt with in further research.

\section{References}

Aijmer, Karin. 1996. Conversational routines in English: convention and creativity. London: Longman.

Austin, John L. 1962. How to do things with words. Oxford: Clarendon Press.

Bates, Elizabeth. 1976. Language and Context. The acquisition of pragmatics. New York: Academic Press.

Biesenbach-Lucas, Sigrun. 2007. Students writing emails to faculty: An examination of epoliteness among native and non-native speakers of English. Language Learning and Technology. 11.59-81.

Blum-Kulka, Shoshana. 1987. Indirectness and politeness in requests: Same or different? Journal of Pragmatics 11 (2). 131-146.

Blum-Kulka, Shoshana, Juliane House, \& Gabriele Kasper (Eds.). 1989. Cross-cultural pragmatics: Requests and apologies. Norwood NJ: Ablex.

Blum-Kulka, Shoshana, \& Elite Olshtain. 1984. Requests and apologies: A cross cultural study of speech act realization patterns (CCSARP). Applied Linguistics 5 (3). 196-213.

Bou-Franch, Patricia. 2011. Openings and closings in Spanish E-mail conversations. Journal of Pragmatics 43 (6). 1772-1785.

Brown, Penelope, \& Stephen Levinson. 1987. Politeness: Some universals in language usage. Cambridge; New York: Cambridge University Press.

Brown, Roger, \& Albert Gilman. 1960. The pronouns of power and solidarity. In Thomas Sebeok (Ed.) Style in Language. 253-276. New York/London: MIT Press.

Brothers, Leslie, \& Brian Ring. 1992. A Neuroethological framework for the representation of minds. Journal of Cognitive Neuroscience 4 (2). 107-118.

Byon, Andrew S. 2006. The role of linguistic indirectness and honorifics in achieving linguistic politeness in Korean requests. Journal of Politeness Research 2 (2). 247-276.

Chejnová, Pavla. 2014. Expressing politeness in the institutional e-mail communications of university students in the Czech Republic. Journal of Pragmatics 60. 175-192.

Chen, Xinren. 2014. Politeness processing as situated social cognition: A RT-theoretic account. Journal of Pragmatics 71. 117-131.

Clark, Herbert H. 1979. Responding to indirect speech acts. Cognitive Psychology 11. 430477.

Clark, Herbert H., \& Dale H. Schunk. 1980. Polite responses to polite requests. Cognition. 8. 111-143. 
Danblon, Emmanuelle, Bernard de Clerck, \& Jean-Pierre van Noppen. 2005. Politeness in Belgium: Face, distance and sincerity in service-exchange rituals. In Leo Hickey \& Miranda Stewart (Eds.). Politeness in Europe, 45-57. Clevedon: Multilingual Matters.

Davis, Wayne. 1998. Implicature. Cambridge: Cambridge University Press.

De Clerck, Bernard. 2006. The Imperative in English: A Corpus-based, Pragmatic Analysis. $\mathrm{PhD}$ diss., Universiteit Gent.

Ervin-Tripp, Susan. 1976. Is Sybil there?, The structure of American English directives. Language in Society 5. 25-66.

Escandell-Vidal, Victoria. 1998. Politeness: A relevant issue for relevance theory. Revista Alicantina de Estudios Ingleses 11. 45-57.

Escandell-Vidal, Victoria. 2004. Norms and principles: Putting social and cognitive pragmatics together. In Rosina Márquez-Reiter \& María E. Placencia (Eds.) Current Trends in the Pragmatics of Spanish. 347-371. Amsterdam: Benjamins.

Fiengo, Robert. 2007. Asking questions: Using meaningful structures to imply ignorance. Oxford: Oxford University Press.

Flöck, Ilka. 2016. Requests in American and British English. A contrastive multi-method analysis. Amsterdam: John Benjamins.

Fraser, Bruce. 2005. Whither politeness. In Robin Lakoff \& Sachiko Ide (Eds.) Broadening the horizons of linguistic politeness. 65-83. Amsterdam: John Benjamins.

Haugh, Michael, 2015. Im/Politeness implicatures. Berlin: Mouton de Gruyter.

Holtgraves, Thomas M., \& Joong-Nam Yang. 1990. Interpersonal underpinnings of request strategies: general principles and differences due to culture and gender. Journal of Personality and Social Psychology 59 (4). 719-729.

Jary, Mark. 1998a. Is relevance theory social? Revista Alicantina de Estudios Ingleses 11. 157-169.

Jary, Mark. 1998b. Relevance theory and the communication of politeness. Journal of Pragmatics 30. 1-19.

Johnson, Mark. 1987. The body in the mind. Chicago: University of Chicago Press.

Karmiloff-Smith, Annette. 1992. Beyond modularity: A developmental perspective on cognitive science. Cambridge, MA: MIT Press/Bradford Books.

Karmiloff-Smith, Annette, Edward Klima, Ursula Bellugi, \& Simon Baron-Cohen. 1995. Is there a social module? Language, face processing, and theory of mind in individuals with williams syndrome. Journal of Cognitive Neuroscience 7 (2). 196-208.

Kerbrat-Orecchioni, Catherine. 2004. Politeness in France: How to buy bread politely. In Leo Hickey \& Miranda Stewart (Eds.) Politeness in Europe. 29-44. Clevedon: Multilingual Matters.

Lee, James J., \& Steven Pinker. 2010. Rationales for indirect speech: The theory of the strategic speaker. Psychological Review 117 (3). 785-807.

Leech, Geoffrey. 1983. Principles of pragmatics. London: Routledge.

Leech, Geoffrey. 2014. The pragmatics of politeness. Oxford: Oxford University Press. 
Leichty, Greg \& James L. Applegate 1991. Social-cognitive and situational influences on the use of face-saving persuasive strategies. Human Communication Research 17 (3). 451484.

Levinson, Stephen. 2012. Interrogative intimations: On a possible social economics of interrogatives. In Jan P. de Ruiter (Ed.) Questions: Formal, Functional, and Interactional Perspectives. 11-32. Cambridge: Cambridge University Press.

Lim, Tae-Seop \& John W. Bowers 1991. Facework solidarity, approbation, and tact. Human Communication Research 17 (3). 415-451.

Manno, Giuseppe. 1999. Le remerciement prospectif, ou la condensation de l'échange directif. Pour une conception plus dialogale des actes de discours. Cahiers Ferdinand de Saussure 52. 203-235.

Manno, Giuseppe. 2002. La politesse et l'indirection: Un essai de synthèse. Langage \& Société 100 (2). 5-47.

Martiny, Thierry. 1996. Forms of address in French and Dutch: A sociopragmatic approach. Language Sciences 18 (3-4). 765-775.

Ogiermann, Eva. 2009. Politeness and in-directness across cultures: A comparison of English, German, Polish and Russian requests. Journal of Politeness Research 5. 189216.

Pérez Hernández, Lorena. 2013. Illocutionary constructions: (Multiple source)-in-target metonymies, illocutionary ICMs, and specification links. Language and Communication 33. 128-149.

Pérez Hernández, Lorena, \& Francisco José Ruiz de Mendoza. 2002. Grounding, semantic motivation, and conceptual interaction in indirect directive speech acts. Journal of Pragmatics 35. 259-284.

Pinker, Steven, Martin A. Nowak, \& James J. Lee. 2008. The logic of indirect speech. PNAS 105 (3). 833-838.

Roulet, Eddy. 1980. Modalité et illocution. Communications 32. 216-239.

Ruytenbeek, Nicolas. 2017. The mechanics of indirectness: A case study of directive speech acts. $\mathrm{PhD}$ diss., Université libre de Bruxelles.

Ruytenbeek, Nicolas, Ekaterina Ostashchenko, \& Mikhail Kissine. 2017. Indirect request processing, sentence types and illocutionary forces. Journal of Pragmatics 119. 46-62.

Saeli, Hooman. 2016. Persian favor asking in formal and informal academic contexts: The impact of gender and academic status. Pragmatics 26 (2). 315-344.

Searle, John. R. 1975. Indirect speech acts. In Peter Cole \& Jerry L. Morgan (Eds.) Vol. 3, Speech Acts, Syntax and Semantics. 59-82. New York: Academic Press.

Soltys, Jessica, Marina Terkourafi, \& Napoleon Katsos. 2014. Disentangling politeness theory and the strategic speaker approach: theoretical considerations and empirical predictions. Intercultural Pragmatics 11(1). 31-56.

Sperber, Dan, \& Deirdre Wilson. 1995. Relevance: Communication and cognition, $2^{\text {nd }}$ ed. Oxford: Blackwell.

Sweetser, Eve E., 1990. From etymology to pragmatics: metaphorical and cultural aspects of semantic structure. Cambridge: Cambridge University Press. 
Talmy, Leonard. 2000. Toward a cognitive semantics. Vol. 1, Concept Structuring Systems. Cambridge, MA: MIT Press.

Terkourafi, Marina. 2003. Generalized and particularized implicatures of linguistic politeness. In Peter Kühnlein, Hannes Rieser, \& Henk Zeevat (Eds.) Perspectives on dialogue in the new millennium. 149-164. Amsterdam/Philadelphia: John Benjamins.

Terkourafi, Marina. 2008. Toward a unified theory of politeness, impoliteness, and rudeness. In Derek Bousfield \& Miriam A. Locher (Eds.) Impoliteness in language, studies on its interplay with power in theory and practice, language, power and social process. 45-74. Berlin: Mouton de Gruyter.

Terkourafi, Marina. 2011. The puzzle of indirect speech. Journal of Pragmatics 43. 28612865.

Terkourafi, Marina. 2014. The importance of being indirect. Belgian Journal of Linguistics 28. 45-70.

Terkourafi, Marina. 2015. Conventionalization: A new agenda for im/politeness research. Journal of Pragmatics 86. 11-18.

Van Olmen, Daniel. 2011. "The Imperative in English and Dutch. A Functional Analysis in Comparable and Parallel Corpora." PhD diss., Universiteit van Antwerpen.

Van Mulken, Margot. 1996. Politeness markers in French and Dutch requests. Language Sciences 18 (3-4). 689-702.

Warga, Muriel. 2005. 'Est-ce que tu pourrais m'aider?' vs. 'Je voudrais te demander si tu pourrais m'aider.' Les Requêtes en Français Natif et en Interlangue. Vox Romanica : Annales Helvetici Explorandis Linguis Romanis Destinati 64. 141-159.

Yu, Kyong-Ae. 2011. Culture-specific concepts of politeness: Indirectness and politeness in English, Hebrew, and Korean requests. Intercultural Pragmatics 8 (3). 385-409.

Yuan, Yi. 2001. An enquiry into empirical pragmatics data gathering methods: Written DCTs, Oral DCTs, field notes, and natural conversations. Journal of Pragmatics 33(2). 271-292. 
Appendices

Appendix 1 - External and internal modifications (cf. CCSARP)

\begin{tabular}{|c|c|c|}
\hline & Examples (French) & English translation \\
\hline \multicolumn{3}{|l|}{$\begin{array}{l}\text { External } \\
\text { modifications }\end{array}$} \\
\hline \multicolumn{3}{|l|}{ Supportive moves } \\
\hline Opening & $\begin{array}{l}\text { Bonjour } \\
\text { Salut } \\
\text { Cher/chère } \\
\text { M. / Mme / Mlle }\end{array}$ & $\begin{array}{l}\text { 'Good } \\
\text { morning/afternoon/evening' } \\
\text { 'Hello' } \\
\text { 'Dear' } \\
\text { 'Mr.', 'Mrs.', 'Miss' } \\
\end{array}$ \\
\hline Self-introduction & $\begin{array}{l}\text { Je suis } X, \text { chargée de la } \\
\text { rédaction... } \\
\text { Je suis une étudiante... } \\
\text { Je suis la rédactrice... }\end{array}$ & $\begin{array}{l}\text { 'I am X, responsible for the } \\
\text { writing...' } \\
\text { 'I am a student...' } \\
\text { 'I am the editor...' }\end{array}$ \\
\hline Orientation move & $\begin{array}{l}\text { Je suis en train de finaliser la } \\
\text { publication de la revue des } \\
\text { étudiants. }\end{array}$ & $\begin{array}{l}\text { 'I am finalizing the publication of } \\
\text { the student journal.' }\end{array}$ \\
\hline Explicit criticism & $\begin{array}{l}\text { Tu étais chargée de la } \\
\text { rédaction de ce dernier et je } \\
\text { n'ai pourtant eu aucun retour. }\end{array}$ & $\begin{array}{l}\text { 'You were responsible for writing } \\
\text { this article but I haven't received } \\
\text { anything.' }\end{array}$ \\
\hline $\begin{array}{l}\text { Checking on } \\
\text { preconditions }\end{array}$ & $\begin{array}{l}\text { Si vous souhaitez toujours } \\
\text { que votre texte paraisse dans } \\
\text { la revue, ... } \\
\text { Pourriez-vous me confirmer } \\
\text { votre participation? }\end{array}$ & $\begin{array}{l}\text { 'If you still want your text to be } \\
\text { published in the journal, ...' } \\
\text { 'Could you confirm your } \\
\text { participation?' }\end{array}$ \\
\hline Grounder & $\begin{array}{l}\text { Je ne peux clôturer la } \\
\text { publication sans votre texte. } \\
\text { J'en ai besoin pour finaliser } \\
\text { la revue. }\end{array}$ & $\begin{array}{l}\text { 'I cannot complete the publication } \\
\text { without your text.' } \\
\text { 'I need it in order to finalize the } \\
\text { journal.' }\end{array}$ \\
\hline \multicolumn{3}{|l|}{$\begin{array}{l}\text { Imposition } \\
\text { minimizer }\end{array}$} \\
\hline Apology & $\begin{array}{l}\text { En m'excusant de vous } \\
\text { déranger pendant cette } \\
\text { période chargée de la rentrée } \\
\text { académique... }\end{array}$ & $\begin{array}{l}\text { 'With my apologies for bothering } \\
\text { you in this busy period of the start } \\
\text { of the academic year...' }\end{array}$ \\
\hline Thanks & $\begin{array}{l}\text { Merci de ta compréhension. } \\
\text { Merci d'avance. }\end{array}$ & $\begin{array}{l}\text { 'Thanks for your understanding.' } \\
\text { 'Thank you in advance.' }\end{array}$ \\
\hline Closing: greeting & $\begin{array}{l}\text { Bien à vous... } \\
\text { Cordialement... } \\
\text { Veuillez agréer, cher } \\
\text { monsieur, mes salutations les } \\
\text { plus distinguées. }\end{array}$ & $\begin{array}{l}\text { 'Best wishes...' } \\
\text { 'Sincerely yours...' } \\
\text { 'Please accept, Sir, my very best } \\
\text { regards.' }\end{array}$ \\
\hline $\begin{array}{l}\text { Closing: phatic } \\
\text { element }\end{array}$ & $\begin{array}{l}\text { Bonne journée. } \\
\text { J'espère que tout se passe } \\
\text { bien de ton côté. }\end{array}$ & $\begin{array}{l}\text { 'I wish you a nice day.' } \\
\text { 'I hope all is fine with you.' }\end{array}$ \\
\hline
\end{tabular}




\begin{tabular}{|c|c|c|}
\hline \multicolumn{3}{|l|}{ Aggravating moves } \\
\hline Impatience & $\begin{array}{l}\text { Vous n'avez toujours pas } \\
\text { envoyé votre texte. }\end{array}$ & 'You still have not sent your text.' \\
\hline $\begin{array}{l}\text { Emphasis on } \\
\text { urgency }\end{array}$ & $\begin{array}{l}\text { Nous avons des délais à } \\
\text { respecter. } \\
\text { Nous devons bientôt } \\
\text { envoyer la revue à } \\
\text { l'imprimerie. } \\
\text { J'attends votre texte avec } \\
\text { impatience. }\end{array}$ & $\begin{array}{l}\text { 'We have deadlines to observe.' } \\
\text { 'We have to send the journal to } \\
\text { the press soon.' } \\
\text { 'I look forward to your text.' }\end{array}$ \\
\hline $\begin{array}{l}\text { Emphasis on } \\
\text { positive outcome }\end{array}$ & $\begin{array}{l}\text { En espérant recevoir votre } \\
\text { texte, ... }\end{array}$ & $\begin{array}{l}\text { 'Looking forward to receiving } \\
\text { your text, ...' }\end{array}$ \\
\hline \multicolumn{3}{|l|}{$\begin{array}{l}\text { Internal } \\
\text { modification }\end{array}$} \\
\hline Purpose clause & $\begin{array}{l}\text { afin que je puisse finaliser } \\
\text { la revue }\end{array}$ & 'so that I can finalize the journal' \\
\hline \multicolumn{3}{|l|}{$\begin{array}{l}\text { Syntactic } \\
\text { downgraders }\end{array}$} \\
\hline Conditional & $\begin{array}{l}\text { Pourriez-vous m'envoyer le } \\
\text { texte que vous avez rédigé } \\
\text { pour la revue? }\end{array}$ & $\begin{array}{l}\text { 'Could you send me the text you } \\
\text { have written for the journal?' }\end{array}$ \\
\hline Past tense & $\begin{array}{l}\text { Je me demandais où tu en } \\
\text { étais et si tu vas pouvoir } \\
\text { finir/m'envoyer ton texte... }\end{array}$ & $\begin{array}{l}\text { 'I was wondering what the } \\
\text { situation is and whether you will } \\
\text { be able to finalize/send your } \\
\text { text...' }\end{array}$ \\
\hline \multicolumn{3}{|l|}{$\begin{array}{l}\text { Lexical and phrasal } \\
\text { downgraders }\end{array}$} \\
\hline $\begin{array}{l}\text { Downtoner } \\
\text { (imposition } \\
\text { minimizer) }\end{array}$ & $\begin{array}{l}\text { Ce serait juste pour savoir } \\
\text { si... }\end{array}$ & 'This is just to know whether...' \\
\hline Embedded if-clause & $\begin{array}{l}\text { Si tu peux me l'envoyer, ça } \\
\text { m'arrangerait. }\end{array}$ & $\begin{array}{l}\text { 'If you could send it to me, that } \\
\text { would suit me.' }\end{array}$ \\
\hline Please (politeness) & $\begin{array}{l}\text { s'il vous plait, si vous le } \\
\text { voulez bien, s'il te plait, stp }\end{array}$ & 'please, if you please' \\
\hline $\begin{array}{l}\text { Providing excuses } \\
\text { for the recipient }\end{array}$ & $\begin{array}{l}\text { Il semblerait qu'une erreur } \\
\text { se soit produite dans l'envoi } \\
\text { des articles. }\end{array}$ & $\begin{array}{l}\text { 'It seems that an error occurred } \\
\text { while sending the articles.' }\end{array}$ \\
\hline Hedges & $\begin{array}{l}\text { dans la mesure du possible, } \\
\text { dès que vous aurez un } \\
\text { moment }\end{array}$ & $\begin{array}{l}\text { 'whenever possible, any time you } \\
\text { have a few moments' }\end{array}$ \\
\hline Lexical upgraders & & \\
\hline
\end{tabular}


Appendix 2 - Conventions of means illustrated with examples

\begin{tabular}{|c|c|c|}
\hline Request form & Examples & English translation \\
\hline $\begin{array}{l}\text { Formulaic } \\
\text { Merci de VP }\end{array}$ & $\begin{array}{l}\text { Merci de remédier à cet } \\
\text { oubli. }\end{array}$ & $\begin{array}{l}\text { 'Thanks for rectifying this } \\
\text { omission.' }\end{array}$ \\
\hline $\begin{array}{l}\text { Imperative } \\
\text { Veuillez VP }\end{array}$ & $\begin{array}{l}\text { Veuillez me soumettre votre } \\
\text { texte. }\end{array}$ & 'Please submit your text.' \\
\hline $\begin{array}{l}\text { Explicit } \\
\text { performative }\end{array}$ & $\begin{array}{l}\text { Je vous prie de m'envoyer } \\
\text { votre texte. } \\
\text { Je vous demanderais de } \\
\text { (bien vouloir) m'envoyer } \\
\text { votre texte. } \\
\text { Je vous envoie ce mail afin } \\
\text { de recevoir en réponse votre } \\
\text { texte. } \\
\text { Je vous envoie cet email } \\
\text { comme rappel. }\end{array}$ & $\begin{array}{l}\text { 'I am asking you to send me your } \\
\text { text.' } \\
\text { 'I would ask you to (be willing to) } \\
\text { send me your text.' } \\
\text { 'I send you this email to receive } \\
\text { back your text.' } \\
\text { 'I send you this email as a } \\
\text { reminder.' }\end{array}$ \\
\hline $\begin{array}{l}\text { Hedged } \\
\text { performative }\end{array}$ & $\begin{array}{l}\text { Je me permets de vous } \\
\text { rappeler de me faire } \\
\text { parvenir votre texte. } \\
\text { Je vous prie d'essayer de } \\
\text { me faire parvenir votre } \\
\text { texte. }\end{array}$ & $\begin{array}{l}\text { 'I am taking the liberty to remind } \\
\text { you to send me your text.' } \\
\text { 'Please try to send me your text.' }\end{array}$ \\
\hline Want statement & $\begin{array}{l}\text { J'aimerais que vous me } \\
\text { renvoyiez votre texte. }\end{array}$ & $\begin{array}{l}\text { 'I would like you to send me your } \\
\text { text again.' }\end{array}$ \\
\hline Need statement & $\begin{array}{l}\text { J'aurais besoin que vous me } \\
\text { fournissiez votre texte } \\
\text { rédigé par mail. }\end{array}$ & $\begin{array}{l}\text { 'I would need you to provide the } \\
\text { text you've written by email.' }\end{array}$ \\
\hline $\begin{array}{l}\text { Preparatory } \\
\text { conditions } \\
\text { A's ability }\end{array}$ & $\begin{array}{l}\text { Pourriez-vous me faire } \\
\text { parvenir votre texte? }\end{array}$ & 'Could you send your text to me?' \\
\hline $\begin{array}{l}\text { Hedged preparatory } \\
\text { (A's ability) }\end{array}$ & $\begin{array}{l}\text { Nous aimerions savoir s'il } \\
\text { serait possible que vous } \\
\text { nous fassiez parvenir votre } \\
\text { texte. }\end{array}$ & $\begin{array}{l}\text { 'We would like to know whether } \\
\text { it would be possible for you to } \\
\text { send us your text.' }\end{array}$ \\
\hline $\begin{array}{l}\text { A's } \\
\text { desire/willingness }\end{array}$ & $\begin{array}{l}\text { Auriez-vous l'amabilité de } \\
\text { m'envoyer votre texte? }\end{array}$ & $\begin{array}{l}\text { 'Would you be so kind as to send } \\
\text { me your text?' }\end{array}$ \\
\hline
\end{tabular}




\begin{tabular}{|l|l|l|}
\hline Hints & $\begin{array}{l}\text { Je me permets de vous } \\
\text { envoyer ce mail afin de vous } \\
\text { demander ce qu'il en est. }\end{array}$ & $\begin{array}{l}\text { 'I am taking the liberty to contact } \\
\text { you by mail so as to ask you what } \\
\text { the situation is.' }\end{array}$ \\
$\begin{array}{l}\text { Je reviens vers vous afin de } \\
\text { vous signaler que vous avez } \\
\text { omis de m'envoyer le texte. }\end{array}$ & $\begin{array}{l}\text { 'I am coming back to you to } \\
\text { inform you that you forgot to send } \\
\text { me the text.' }\end{array}$ \\
\hline
\end{tabular}


Appendix 3 - Conventions of means

\begin{tabular}{|l|l|l|}
\hline Convention of means & $\begin{array}{l}\text { Absolute } \\
\text { frequency }\end{array}$ & $\begin{array}{l}\text { Relative } \\
\text { frequency }\end{array}$ \\
\hline Preparatory interrogatives & $80 / 116$ & $69 \%$ \\
Ability interrogatives & $77 / 116$ & $66.4 \%$ \\
Can you VP? & $64 / 116$ & $55.2 \%$ \\
Is it possible to VP? & $12 / 116$ & $10.3 \%$ \\
\hline Explicit performatives & $13 / 116$ & $11.2 \%$ \\
\hline Hints & $7 / 116$ & $6 \%$ \\
\hline Imperatives & $5 / 116$ & $4.3 \%$ \\
\hline Hedged performatives & $5 / 116$ & $4.3 \%$ \\
\hline Speaker's desire/need & $3 / 116$ & $2.6 \%$ \\
\hline Suggestory formula: Thanks for VPing & $3 / 116$ & $2.6 \%$ \\
\hline Obligation statements & $0 / 116$ & $0 \%$ \\
\hline
\end{tabular}

\section{Nicolas Ruytenbeek}

Nicolas Ruytenbeek completed a PhD in Linguistics at the Universite libre de Bruxelles (2017). In his doctoral dissertation, he addressed the mechanics of indirect directive speech acts, both from a theoretical and experimental perspective. His main research interests are speech act comprehension and production, linguistic approaches to politeness, and more generally, issues bearing on the semantics/pragmatics interface. He is currently a postdoctoral researcher at Ghent University (2019-2022). 